\title{
Comparison of the population biology of Epialtus bituberculatus from two rocky shores with distinct hydrodynamic patterns
}

\author{
SAMARA DE PAIVA BARROS-ALVES ${ }^{1,2}$, DOUGLAS FERNANDES RODRIGUES ALVES ${ }^{1,2}$ \\ AND VALTER JOSÉ COBO ${ }^{2,3}$ \\ ${ }^{1}$ Departamento de Zoologia, Instituto de Biociências, Universidade Estadual Paulista - UNESP, Distrito de Rubião Junior, s/n, CEP: \\ 18618-970, Botucatu, São Paulo, Brasil, ${ }^{2}$ NEBECC Group of Studies on Crustacean Biology, Ecology and Culture, ${ }^{3}$ Laboratório de \\ Biologia Marinha-LabBMar, Instituto de Biociências, Universidade de Taubaté-UNITAU
}

\begin{abstract}
The population biology of Epialtus bituberculatus was compared between two different intertidal localities with differing levels of wave exposure. Sampling was conducted monthly between January and December, 2001 on seaweed banks of Sargassum cymosum in the intertidal zone of the rocky shores Grande (GR) $\left(23^{\circ} 23^{\prime} S-45^{\circ} 03^{\prime} W\right)$ and Domingas Dias (DD) $\left(23^{\circ} 29^{\prime} S-45^{\circ} 08^{\prime} W\right)$. Four hundred and twenty-eight crabs were captured at the GR site: 111 juvenile males, 106 adult males, 57 juvenile females, 17 adult females and 137 ovigerous females; while 455 specimens were obtained at the DD site: 76 juvenile males, 113 adult males, 37 juvenile females, 40 adult females and 189 ovigerous females. The population from GR showed a non-normal distribution and from DD a normal distribution. The sex-ratio (female/male) was 1:0.97 at $G R\left(\chi^{2}=0.77, \mathrm{P}=0.084\right)$, whereas it was $1: 1.41$ at $\mathrm{DD}\left(\chi^{2}=13.03, \mathrm{P}<0.001\right)$. The largest individuals occurred at $\mathrm{DD}$ $(\mathrm{U}=78249.0, \mathrm{P}<0.001)$. The estimated size at sexual maturity was 6.3 and $5.0 \mathrm{~mm}$ carapace width $(\mathrm{CW})$ for males, and 5.4 and $5.2 \mathrm{~mm} C W$ for females, from $G R$ and DD, respectively. The observed differences in E. bituberculatus between the studied localities might be explained by the different degrees of wave exposure between sites. However, other factors that might also explain the observed differences (e.g. temperature, salinity and food availability) cannot be discarded as relevant in influencing the population structure between sites herein studied.
\end{abstract}

Keywords: Brachyura, Epialtinae, Epialtus bituberculatus, intertidal, population structure, waves

Submitted 26 March 2012; accepted 10 April 2012; first published online 9 August 2012

\section{INTRODUCTION}

Worldwide, the family Epialtidae has 11 species belonging to the genus Epialtus H. Milne Edwards, 1834, of which only Epialtus bituberculatus H. Milne Edwards, 1834 and Epialtus brasiliensis Dana, 1852 are found in Brazilian waters (Melo, 1998; Ng et al., 2008). Epialtus bituberculatus is found along the western Atlantic Ocean coasts from Florida through the Gulf of Mexico, Antilles, Colombia, Venezuela and Brazil (from Ceará to São Paulo) (Melo, 1998). This species is commonly found on hard bottom, mainly in intertidal shallow waters among algae, mainly in tide-pools (Melo, 1998).

The genus Epialtus seems to be adapted to inhabit the seaweed Sargassum cymosum (C. Agardh, 1820) during its entire post-larval life, because dense populations exist with individuals in all demographic categories (NegreirosFransozo et al., 1994; Teixeira et al., 2008). Among these adaptations, the pointed and curved dactyl of the pereiopods (Castaño \& Campos, 2003) keeps the individuals attached to the seaweed, allowing them to resist the wave impact. The occupation of specific microhabitats by marine organisms, as

Corresponding author:

S.P. Barros-Alves

Email: barros_samara@hotmail.com well as the benefits that they provide (e.g. a refuge against predators, facilitation in capturing prey and less abiotic stress) are commonly reported in the literature (Baeza \& Stotz, 2001; Amarasekare, 2003; Wieters et al., 2009).

The wide geographical range of $E$. bituberculatus suggests that it is highly tolerant to different abiotic conditions. Differences among allopatric populations of this species should be expected because many population parameters, including, e.g. population structure and sex-ratio, can be modified through small and/or large spatial scales by the interaction of local biotic and abiotic processes (Guarnieri et al., 2009). Comparing the population biology of a species from different locations can provide information on intraspecific adaptations to different environmental conditions (Stearns, 1992). In addition, environmental pressures are often responsible for phenotypic and genotypic plasticity (Conde \& Díaz, 1989; Baeza et al., 2009, 2010).

Several biological features studied in South America on E. bituberculatus include its distribution (Coelho-Santos \& Coelho, 1995; Melo, 1996, 1998), larval development (Negreiros-Fransozo \& Fransozo, 2001), and fecundity (Cobo \& Barros, 2009). However, comparisons among different populations with respect to size-frequency distribution, sex-ratio and sexual maturity, among others are relatively few.

As reviewed by Jackson (2010), rocky bottoms frequently have a complex topography, and some of the important 
environmental conditions may be influenced by the topographic structure. So, as a consequence of the variable topographic structures from one location to another, the wave exposure becomes an important factor that can modify the dominance patterns of species, depending on their size and ability to maintain themselves on the substrates (Denny et al., 1985; Gaylord, 2000). Therefore, the variation in hydrodynamic intensity may alter the dynamics of the community, the composition of the species and the structure of populations (Denny et al., 1985; Denny \& Wethey, 2001). Furthermore, environmental conditions such as the intensity of the wave impact on the organisms of the intertidal zone leads to consequences such as differences in growth rates, size at maturity, body size, fecundity and breeding period (Hartnoll, 1982; Denny et al., 1985; Cobo \& Barros, 2009). Based on these statements, it is possible to predict that, on locations with greater hydrodynamic intensity, the larger E. bituberculatus tend to be displaced. As a consequence, when populations under different hydrodynamic intensities are compared, there could be variations in density, mean size of individuals, mean size at which they reach sexual maturity and even in sex-ratio for species with sexual dimorphism related to size.

So, the aim of this study was to describe the population structure of E. bituberculatus associated with seaweed banks of S. cymosum, in south-eastern Brazil, in relation to population features (size-class distribution, sex-ratio, breeding period, sexual maturity and juvenile recruitment) and compare the population parameters above between two localities, Grande and Domingas Dias, that differ in hydrodynamic properties. According to Széchy et al. (2001) Grande is an exposed wave action site while Domingas Dias is considered a moderately exposed site.

\section{MATERIALS AND METHODS}

Sampling of crabs was conducted monthly from January through to December 2001 on seaweed banks of Sargassum cymosum in the intertidal zone of the rocky shores Grande (GR) $\left(23^{\circ} 23^{\prime} \mathrm{S}-45^{\circ} \mathrm{O} 3^{\prime} \mathrm{W}\right)$ and Domingas Dias (DD) $\left(23^{\circ} 29^{\prime} \mathrm{S}-45^{\circ} 08^{\prime} \mathrm{W}\right)$ (Figure 1$)$, north-eastern coast of São Paulo in south-eastern Brazil. The samples of S. cymosum were taken from the rocky bottom by the holdfast region, during low tide. The catch effort consisted of two hours/

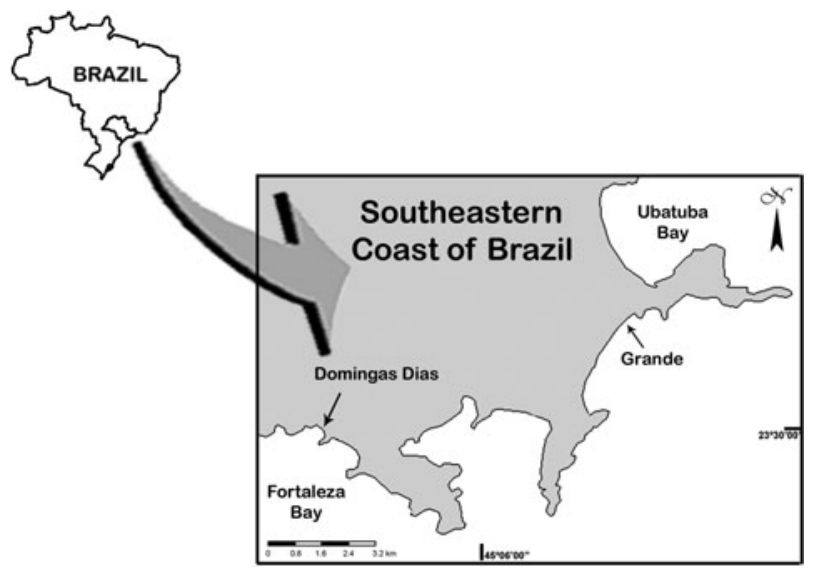

Fig. 1. Map of Brazil indicating the Grande and Domingas Dias rocky shores. month, conducted by two people. The phytal samples were placed in plastic bags and transferred to the Marine Biology Laboratory at the University of Taubaté. In the laboratory, the crabs were removed from the Sargassum by hand. This process was carried out twice, in order to increase collection efficiency, especially for the presence of very small crabs. For each sample, the seaweed volume (L) was measured by the displacement of a water column. This measurement was used to obtain the crab density associated with the phytal (individuals/L).

For each specimen of Epialtus bituberculatus, the greatest carapace width $(\mathrm{CW})$ was measured with a Vernier caliper $(0.1 \mathrm{~mm})$. Sex and developmental stage (juvenile or adult) were identified from the external morphology of the abdomen and appendages, classified as: adult female, large abdomen, covering almost the entire ventral thorax surface; hairy pleopods; adult male, abdomen narrow, with two pairs of small gonopds; juvenile female; and male, triangular shape, 2 and 4 pairs of non-hairy pleopods for males and females respectively (see Haefner, 1990).

The individuals were grouped into eleven $(1 \mathrm{~mm})$ sizeclasses and into demographic classes: juvenile males (JM); adult males (AM); juvenile females (JF); adult females (AF); and ovigerous females (OF).

Normal distributions (modes) were identified and fitted to the monthly frequency distributions through the automatic least-squares method 'Automatic Peak Detection and Fitting, Method I-Residuals', as performed by Pimenta et al. (2005) and Keunecke et al. (2007). Recruitment of juvenile crabs to the benthic population during each month was identified by the presence of modes in the first size-classes. The presence of these small crabs indicates settlement of megalopae from the water column to the benthic environment (Negreiros-Fransozo \& Fransozo, 2001). The normality of the population size distribution was analysed by the ShapiroWilk test $(\alpha=0.05)$. The Mann-Whitney test was applied to compare the length means of the demographic classes $(\alpha=0.05)$. The proportion of males and females was analysed by the Chi-square $\left(\chi^{2}\right)$ test $(\alpha=0.05)$ (Zar, 2010). The relative frequency of adult individuals (\%) was plotted on a size-class graph in order to obtain the size at maturity. The data were fitted to a sigmoid curve, according to the results of the logistic regression, where: $\mathrm{CW}_{50}=$ carapace width at $50 \%$ of adult individuals; and $\mathrm{r}=$ slope of the curve. The equation was adjusted by the least-squares method (Sokal \& Rohlf, 1995; Sampedro et al., 1999; Mura et al., 2005).

\section{RESULTS}

\section{Population structure and density}

A total of 428 specimens of Epialtus bituberculatus were captured in GR, including: 111 juvenile males (25.93\%); 106 adult males (24.77\%); 57 juvenile females (13.32\%); 17 adult females (3.97\%); and 137 ovigerous females (32.01\%). From DD, 455 individuals were obtained: 76 juvenile males (16.70\%); 113 adult males (24.84\%); 37 juvenile females $(8.13 \%) ; 40$ adult females (8.79\%); and 189 ovigerous females (41.54\%) (Table 1 ).

The size-frequency distribution analysis indicated a unimodal and non-normal distribution for the population of GR (W=0.987, $P<0.001$ ), and a unimodal and normal distribution for the population of $\mathrm{DD}(\mathrm{W}=0.995, P>0.001)$ (Figure $2 \mathrm{~A}$ ). However, the crab density by month ranged from 
Table 1. Descriptive data on Epialtus bituberculatus: number of individuals $(\mathrm{N})$, the smallest $(\mathrm{S})$ and the largest $(\mathrm{L})$ carapace width, the mean carapace width, and the standard deviation (mean $\pm \mathrm{SD}$ ) from the sampling sites: Grande (GR) and Domingas Dias (DD) rocky shores.

\begin{tabular}{llrrrr}
\hline $\begin{array}{l}\text { Sampling } \\
\text { location }\end{array}$ & $\begin{array}{l}\text { Demographic } \\
\text { category }\end{array}$ & $\mathbf{N}$ & \multicolumn{3}{c}{ Carapace width (mm) } \\
\cline { 3 - 6 } & & & S & L & Mean \pm SD \\
\hline GR & JM & 111 & 1.6 & 7.9 & $4.7 \pm 1.24$ \\
& AM & 106 & 3.3 & 9.8 & $7.6 \pm 1.23$ \\
& JF & 57 & 3.1 & 6.8 & $5.0 \pm 0.83$ \\
& AF & 17 & 4.2 & 7.9 & $6.2 \pm 1.04$ \\
& OF & 137 & 5.1 & 9.6 & $6.5 \pm 0.69$ \\
& Overall & 428 & 1.6 & 9.8 & $6.6 \pm 1.52$ \\
DD & 76 & 2.5 & 7.9 & $5.1 \pm 1.18$ \\
& JM & 113 & 4.0 & 11.6 & $7.7 \pm 1.41$ \\
& AM & 37 & 3.3 & 6.9 & $5.2 \pm 0.93$ \\
& JF & 40 & 5.2 & 9.8 & $6.7 \pm 0.92$ \\
& AF & 189 & 5.2 & 9.6 & $6.8 \pm 0.76$ \\
& OF & 455 & 2.5 & 11.6 & $6.61 \pm 1.39$ \\
\hline & Overall & & &
\end{tabular}

$\mathrm{JM}$, juvenile male; AM, adult male; JF, juvenile female; $\mathrm{AF}$, adult female; $\mathrm{OF}$, ovigerous female.

1.27 to 25.45 ind./L at GR, in January and September, respectively; and from 3.11 to 34.67 ind./L at DD, in January and May, respectively (Figure $2 \mathrm{~B}$ ). No significant differences in density of $E$. bituberculatus between the two sampled localities were found (Mann - Whitney test; $U=52.00, P=0.240$ ).

Concerning the size-class distribution, we found that differences range in body size between sites. From GR, no individual was observed in the size-classes from 9.5 to $12.5 \mathrm{~mm} \mathrm{CW}$ (Figure 3A), while no specimen was recorded in the size-classes from 1.5 to $2.5 \mathrm{~mm} \mathrm{CW}$ for $\mathrm{DD}$ (Figure $3 \mathrm{~B}$ ). Juveniles were observed within size-classes $7.5-$ $8.5 \mathrm{~mm} \mathrm{CW}$ and ovigerous females were registered between the size-classes $4.5-5.5$ to $9.5-10.5 \mathrm{~mm} \mathrm{CW}$ at both sampled sites (Figure 3 ). The average body size and the range in body size of E. bituberculatus differed between localities (Tables 1 \& 2). No significant differences were found between size by males and females at both sites (Mann-Whitney test; $U=22338.0, P=0.664$ ) (Table 2).

\section{Population dynamics}

Juveniles were recorded over the entire sampling period at both sites, except in November at DD. The highest peaks of juveniles occurred during May and June at GR, with 100\% and 90\% of the individuals sampled during the respective months (Figure $4 \mathrm{~A}$ ). At DD, the main peaks of juvenile frequency were recorded from July to August, although these peaks were less marked than those observed at GR (Figure $4 \mathrm{~B}$ ). Ovigerous females occurred in all the samples from both sites, except in May at GR. There was also a period of lower frequency of ovigerous females from May to August (Figure 4). The modes of highest mean size for the first size-classes occurred in April and October at DD (Figure 5). The number of juveniles captured was 168 and 113 from the GR and $\mathrm{DD}$, about $40 \%$ and $25 \%$ of the total, respectively. Juvenile recruitment was continuous during the year at both sites. This is supported by the presence of modes in the first size-classes through all months at both sites. Reproduction was continuous during the year at the two study sites (Figure 5).

\section{Size at first maturity}

The carapace width at $50 \%$ of adult individuals was 5.4 and $5.2 \mathrm{~mm} \mathrm{CW}$ for females from GR and DD, respectively, i.e. in the same size-class of 4.5 to $5.5 \mathrm{~mm} \mathrm{CW}$ (Figure 6A, B). However, the smallest ovigerous female had $5.1 \mathrm{~mm} \mathrm{CW}$ at $\mathrm{GR}$ and $5.2 \mathrm{~mm} \mathrm{CW}$ at DD. For the males, the CW at $50 \%$ of adult individuals differed between the sites, 6.3 and $5.0 \mathrm{~mm} \mathrm{CW}$ at GR and DD, respectively (Figure 6C, D).

\section{Sex-ratio}

The sex-ratio (female/male) was 1:0.97 at GR $\left(\chi^{2}=0.77, P=\right.$ $0.084)$ and $1: 1.41$ at $\mathrm{DD}\left(\chi^{2}=13.03, P<0.001\right)$. Thus, overall sex-ratio was male biased in DD but not in GR (i.e. higher number of females in relation to males at DD). Deviations from these ratios were observed in June and July at GR, and in January, June, July, August and December at DD (Figure 7). Deviations from a 1:1 sex-ratio were also recorded among the size-classes, with a concentration of males in the extreme classes, and females in the intermediate classes, the ovigerous females being the most numerous (Figure 8).

\section{DISCUSSIDN}

\section{Population structure and density}

The unimodal distribution of both populations with the modes at intermediate size-classes suggests that the
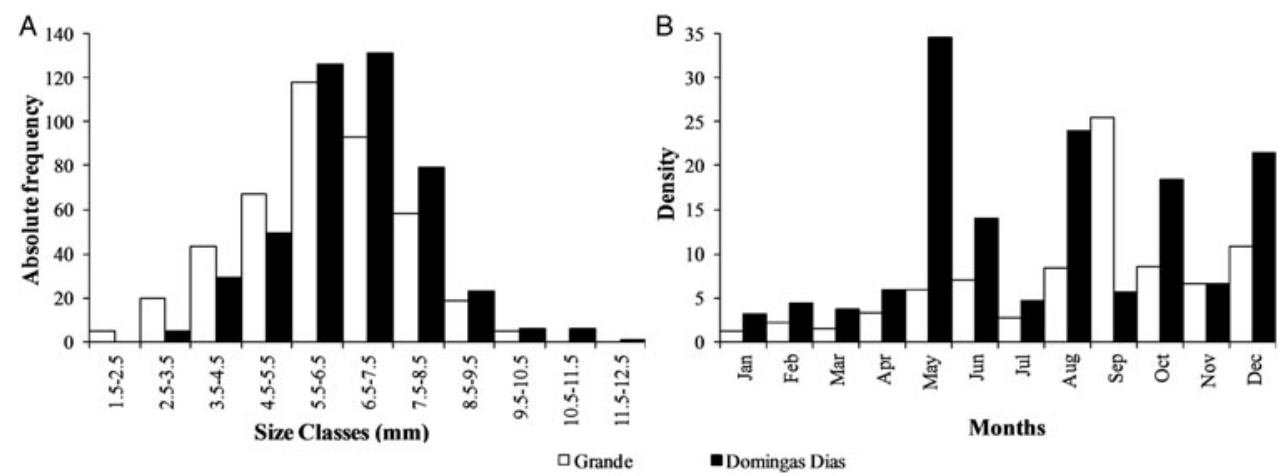

Fig. 2. Absolute frequency by size-class (A) and density by months (B) of Epialtus bituberculatus individuals from the rocky shores Grande and Domingas Dias, Ubatuba, Brazil. 


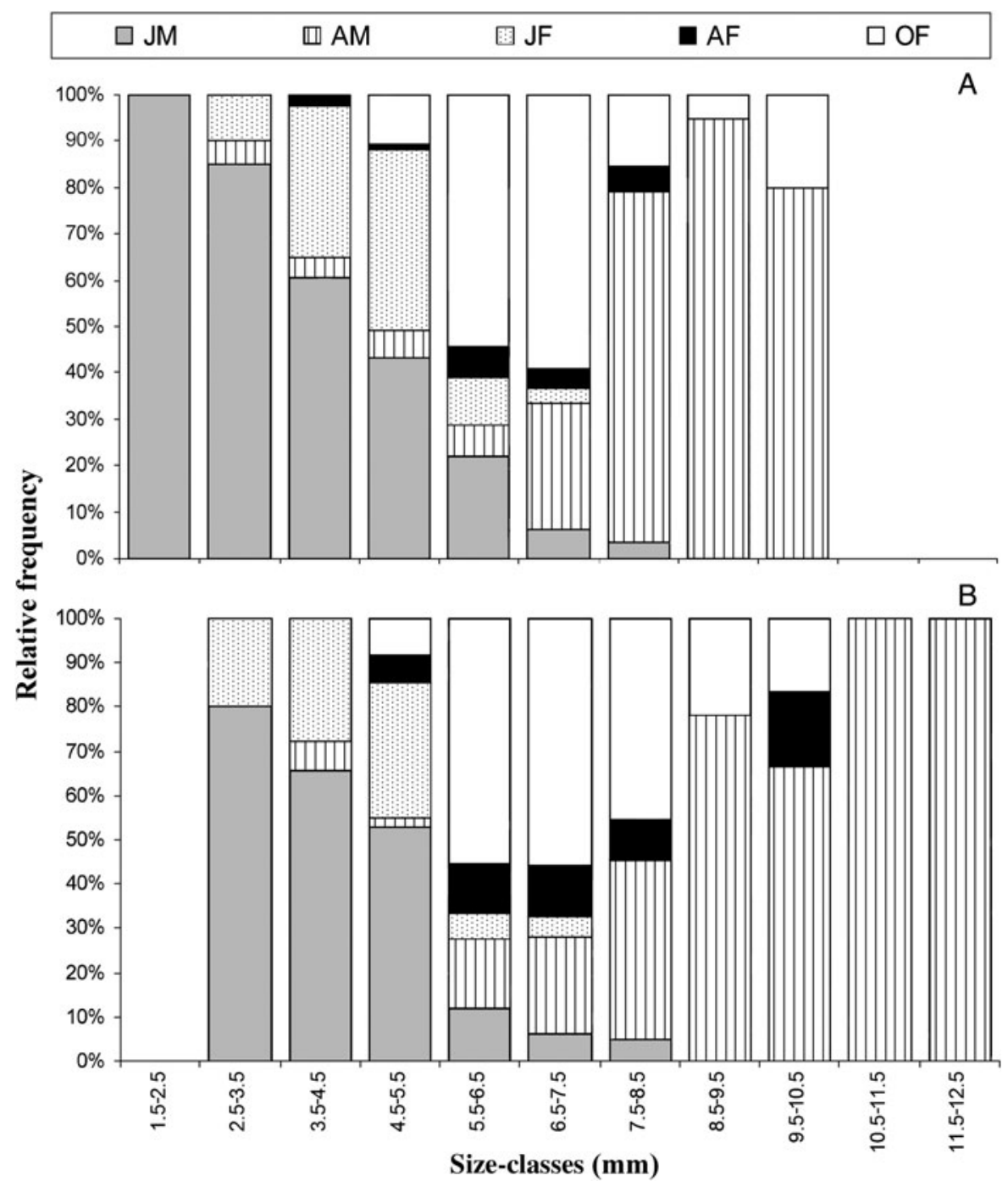

Fig. 3. Relative frequency by size-class of Epialtus bituberculatus from the rocky shores Grande (A) and Domingas Dias (B), Ubatuba, Brazil. JM, juvenile male; $\mathrm{AM}$, adult male; JF, juvenile female; AF, adult female; OF, ovigerous female.

Table 2. Results of statistical comparisons between the means for carapace width of Epialtus bituberculatus. Mann-Whitney test values $(U)$.

\begin{tabular}{lrc}
\hline Relationship & \multicolumn{1}{c}{$\boldsymbol{P}$} \\
\hline JM DD vs JM GR & 3504.00 & $0.049^{*}$ \\
AM DD vs AM GR & 5870.50 & 0.800 \\
M DD vs M GR & 17668.00 & $0.016^{*}$ \\
JF DD vs JF GR & 899.00 & 0.228 \\
AF DD vs AF GR & 262.00 & 0.173 \\
OF DD vs OF GR & 9543.00 & $<0.001^{*}$ \\
F DD vs F GR & 10558.00 & $<0.001^{*}$ \\
M DD vs F DD & 24778.00 & 0.794 \\
M GR vs F GR & 22338.00 & 0.664 \\
DD vs GR & 78249.00 & $<0.001^{*}$ \\
\hline
\end{tabular}

vs, versus; M, male; F, female; DD, Domingas Dias; GR, Grande; JM, juvenile male; AM, adult male; JF, juvenile female; AF, adult female; OF, ovigerous female; ${ }^{*}$, significant values.

populations maintain constant rates of recruitment, mortality, and/or migration. This pattern is very common among majoid crabs (Table 3) and in general in decapods in tropical areas where marked climatic alterations do not occur (Warner, 1967; Díaz \& Conde, 1989; Hartnoll \& Bryant, 1990). At $\mathrm{GR}$, the unimodal distribution was also a non-normal distribution. However, we suggest that a balance between inputs and outputs of individuals might occur in this population as well. Despite the observed differences in wave energy between the sites, the density of E. bituberculatus seems unaffected by this disturbance factor. We found no significant differences in crab density between the rocky shores. Therefore, the energy of wave impact seemed not be a limiting factor for the species occurrence, possibly because the individuals find a refuge in the Sargassum banks.

Males predominated in the largest size-classes, which according to Gherardi \& Micheli (1989) is to be expected, because males tend to attain larger dimensions, probably to ensure mating and to win intraspecific competitions, as reported for other majoid crabs in the review of the literature realized for this study (see Table 3). Christy \& Salmon (1984) and Abrams (1988) reported that the energy allocated to growth is used for structural metabolism in males and for egg production in females, which determines sexual 


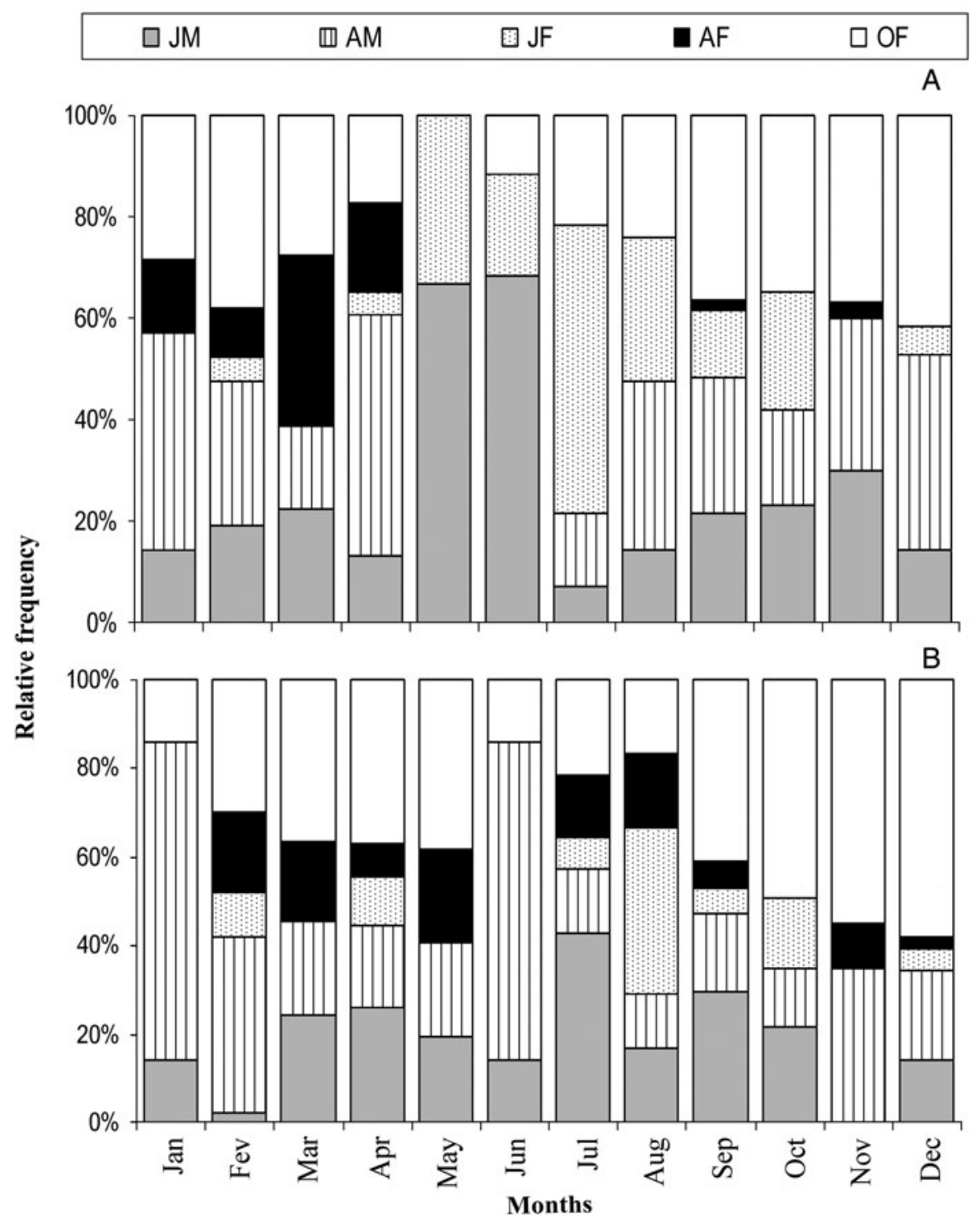

Fig. 4. Monthly relative frequency of Epialtus bituberculatus from the rocky shores Grande (A) and Domingas Dias (B), Ubatuba, Brazil. JM, juvenile male; AM, adult male; JF, juvenile female; AF, adult female; OF, ovigerous female.

dimorphism in body size (males larger than females) and ultimately assures sex-specific optimization of fecundity and fitness.

The differences observed in population structure between the two E. bituberculatus populations seemed to be, at least partially, constrained by the different intensities of wave energy received at GR and DD. This hydrodynamic influence could be important for the establishment of patterns for some population features of E. bituberculatus, e.g. sex-ratio and sexual maturity relationships, which could be affected by hydrodynamic conditions.

\section{Population dynamics}

The presence of ovigerous females during the entire study period at both sites, except in May at GR, suggests that E. bituberculatus has continuous reproduction in the region. This reproductive strategy seems to be common among brachyuran species in tropical or subtropical areas (DeVries et al., 1983;
Pinheiro \& Fransozo, 2002; Litulo, 2004; Cobo, 2006). The continuous production of larvae resulted in continuous recruitment of juveniles at both beaches. This may partially explain some features of both populations, such as the stable abundance and unimodal frequency distribution. Continuous recruitment was also observed for other majoid crabs, such as Mithraculus forceps (A. Milne-Edwards, 1875) by Cobo (2006) in the region of Ubatuba, south-eastern Brazil.

\section{Size at first maturity}

At Grande beach females became mature at smaller sizes than males, as reported for other Majoidea species (Table 3), indicating that females can attain reproductive stages by accumulating energetic resources in size-classes, which are better for reproduction, delaying the somatic growth, as assigned by Hartnoll (1982). In contrast, at Domingas Dias beach, both males and females attained morphological maturity at similar sizes. Wave exposure might be producing the observed 

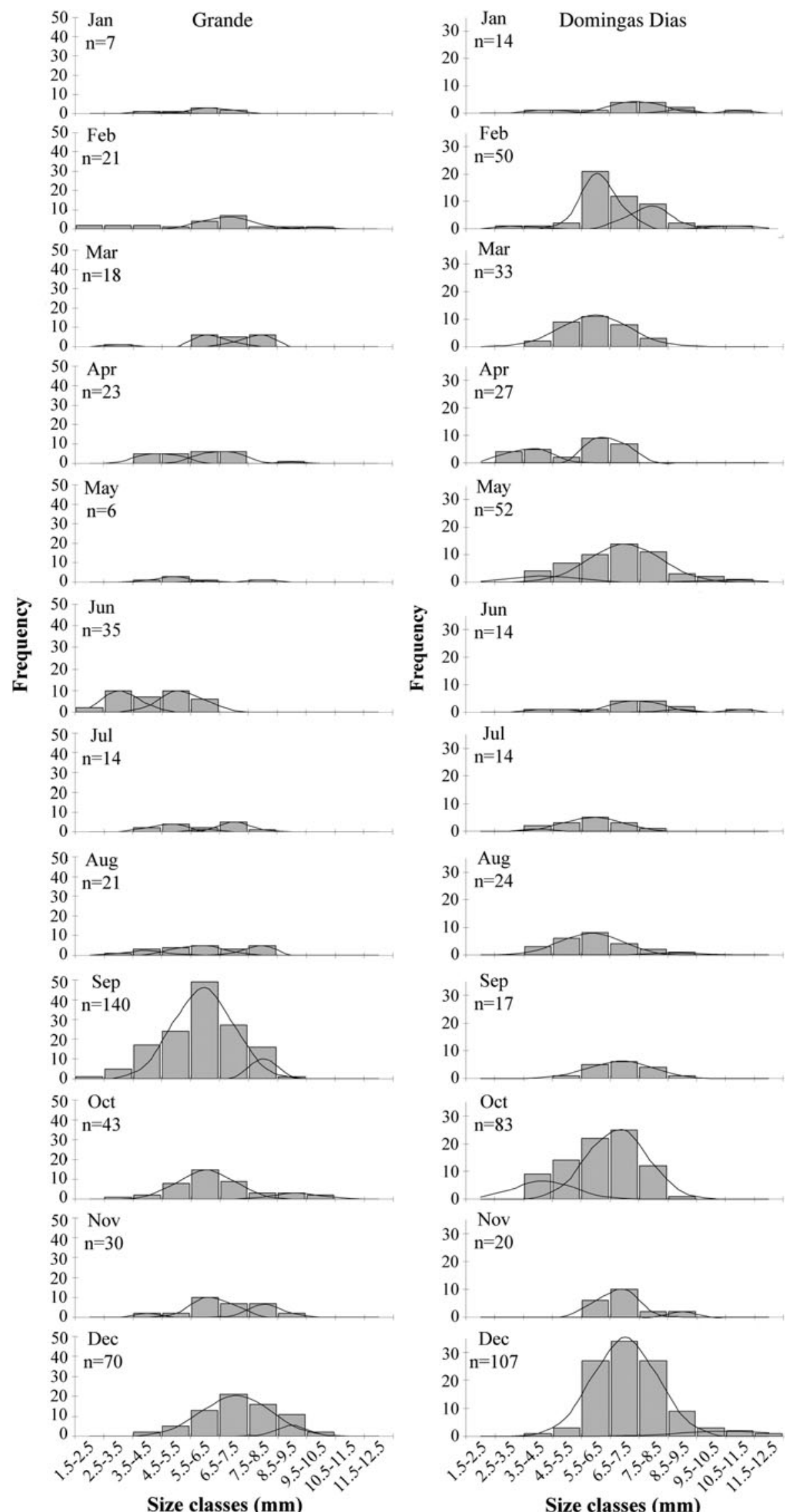

Size classes $(\mathrm{mm})$

Size classes $(\mathrm{mm})$

Fig. 5. Monthly distribution of Epialtus bituberculatus from the rocky shores Grande and Domingas Dias, Ubatuba, Brazil. 

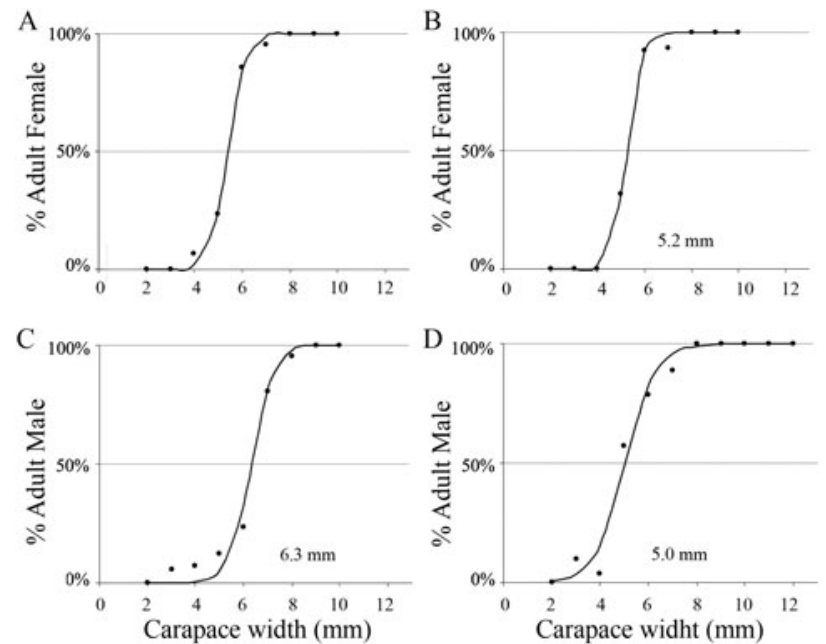

Fig. 6. Adjustment of the logarithmic function indicating the carapace width at $50 \%$ of adult individuals $\left(\mathrm{CW}_{50}\right)$ of Epialtus bituberculatus. (A) Females from Grande rocky shore; (B) females from Domingas Dias rocky shore; (C) males from Grande rocky shore; (D) males from Domingas Dias rocky shore.

differences in size at first maturity in females because they allocate energy to resist this strong wave exposure and cannot allocate in parallel energy to the female function at that particular site, since environmental parameters are important for determining energy allocation in decapod crustaceans (Jones \& Simons, 1983; Bertini et al., 2010).

In the other site with less exposure, females can mature earlier as they do not need to resist wave exposure and thus can invest to reproduction earlier in life than in the more

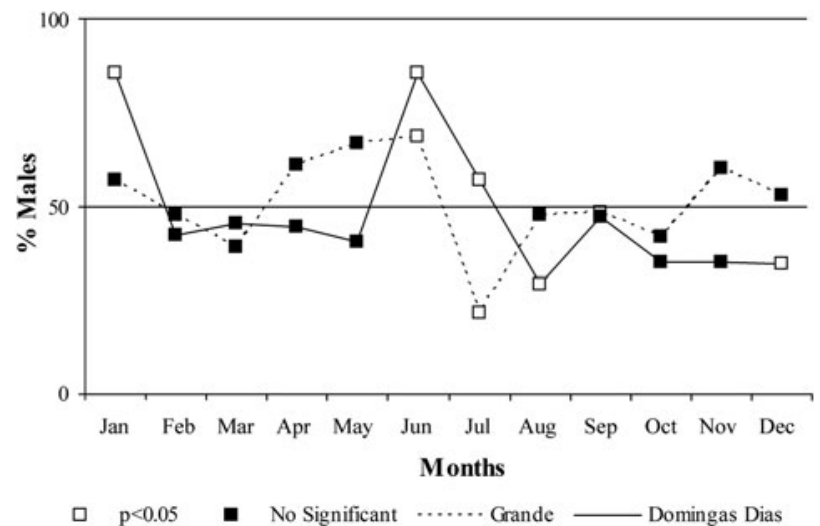

Fig. 7. Monthly relative frequency of Epialtus bituberculatus males from the rocky shores Grande and Domingas Dias, Ubatuba, Brazil.

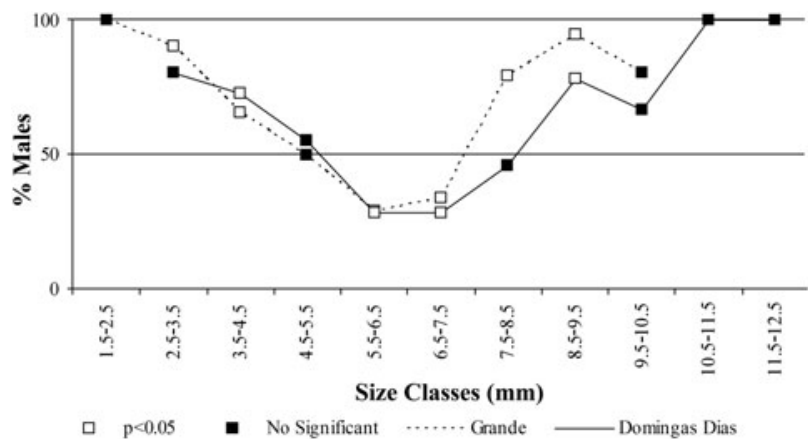

Fig. 8. Relative frequency by size-class of Epialtus bituberculatus males from the rocky shores and Domingas Dias, Ubatuba, Brazil.

Table 3. Review of the literature realized for this study of some population features between Epialtus bituberculatus and other species of Majoidea.

\begin{tabular}{|c|c|c|c|c|c|c|c|}
\hline Reference & Location & Species & SP & MP & Distr & AS & Mat \\
\hline Sanz-Brau, 1989 & Western Mediterranean & $\begin{array}{l}\text { Acanthonyx lunulatus } \\
\quad \text { (Risso, 1816) }\end{array}$ & $1: 1$ & - & - & - & - \\
\hline $\begin{array}{l}\text { Negreiros-Fransozo } \\
\quad \text { et al., } 1994\end{array}$ & South-eastern Brazil & $\begin{array}{l}\text { Epialtus brasiliensis (Dana, } \\
\text { 1852) }\end{array}$ & $1: 1$ & - & - & $\begin{array}{l}\text { Female } \\
\text { smaller }\end{array}$ & $\begin{array}{l}\text { Female } \\
\text { smaller }\end{array}$ \\
\hline López-Greco et al., 2000 & Margarita Island, Venezuela & $\begin{array}{l}\text { Microphrys bicornutus } \\
\text { (Latreille, 1825) }\end{array}$ & $1: 1$ & Uni & - & $\begin{array}{l}\text { No } \\
\quad \text { difference }\end{array}$ & - \\
\hline \multirow[t]{2}{*}{$\begin{array}{l}\text { Villalejo-Fuerte et al., } \\
2001\end{array}$} & Gulf of California, Mexico & $\begin{array}{l}\text { Stenocionops ovata } \\
\quad(\text { Bell, 1835) }\end{array}$ & $3.5: 1$ & - & - & $\begin{array}{l}\text { Female } \\
\text { smaller }\end{array}$ & - \\
\hline & & $\begin{array}{l}\text { Maiopsis panamensis } \\
\quad \text { (Faxon, 1893) }\end{array}$ & 1.63:1 & - & - & $\begin{array}{l}\text { Female } \\
\text { smaller }\end{array}$ & - \\
\hline Mantelatto et al., 2003 & $\begin{array}{l}\text { Anchieta Island, Ubatuba, } \\
\text { south-eastern Brazil }\end{array}$ & $\begin{array}{l}\text { Mithraculus forceps (A. } \\
\text { Milne-Edwards, 1875) }\end{array}$ & $1.4: 1$ & Uni & Normal & $\begin{array}{l}\text { Female } \\
\text { smaller }\end{array}$ & - \\
\hline Cobo, 2006 & $\begin{array}{l}\text { Couves Island, Ubatuba, } \\
\text { south-eastern Brazil }\end{array}$ & $\begin{array}{l}\text { Mithraculus forceps (A. } \\
\text { Milne-Edwards, 1875) }\end{array}$ & 1:0.76 & Uni & Normal & $\begin{array}{l}\text { Female } \\
\text { smaller }\end{array}$ & $\begin{array}{l}\text { Female } \\
\text { smaller }\end{array}$ \\
\hline Creasey et al., 1997 & $\begin{array}{l}\text { Oman coast, north-west Arabian } \\
\text { Sea }\end{array}$ & $\begin{array}{l}\text { Encephaloides armstrongi } \\
\quad \text { (Wood-Mason, 1891) }\end{array}$ & $3 \cdot 3: 1$ & - & - & - & - \\
\hline Teixeira et al., 2008 & $\begin{array}{l}\text { Grande beach, Ubatuba, } \\
\text { south-eastern Brazil }\end{array}$ & $\begin{array}{l}\text { Epialtus brasiliensis (Dana, } \\
\text { 1852) }\end{array}$ & 1:1 & Uni & - & - & - \\
\hline Batista et al., 2009 & João Pessoa, north-eastern Brazil & $\begin{array}{l}\text { Microphrys bicornutus } \\
\quad \text { (Latreille, 1825) }\end{array}$ & $1: 1$ & Uni & - & - & - \\
\hline Teixeira et al., 2009 & Ubatuba, south-eastern Brazil & $\begin{array}{l}\text { Acanthonyx scutiformis } \\
\text { (Dana, 1851) }\end{array}$ & $0.8: 1$ & Uni & - & - & $\begin{array}{l}\text { Female } \\
\text { smaller }\end{array}$ \\
\hline This study & $\begin{array}{l}\text { Rocky shore of the Grande beach, } \\
\text { Ubatuba, south-eastern Brazil }\end{array}$ & $\begin{array}{l}\text { Epialtus bituberculatus }(\mathrm{H} . \\
\text { Milne Edwards, 1834) }\end{array}$ & $1: 1$ & Uni & Non-normal & $\begin{array}{l}\text { Female } \\
\text { smaller }\end{array}$ & $\begin{array}{l}\text { Female } \\
\text { smaller }\end{array}$ \\
\hline This study & $\begin{array}{l}\text { Rocky shore of the Domingas } \\
\text { Dias beach, Ubatuba, } \\
\text { south-eastern Brazil }\end{array}$ & $\begin{array}{l}\text { Epialtus bituberculatus (H. } \\
\text { Milne Edwards, 1834) }\end{array}$ & $1: 1.41$ & Uni & Normal & $\begin{array}{l}\text { Female } \\
\text { smaller }\end{array}$ & $\begin{array}{l}\text { Male } \\
\text { smaller }\end{array}$ \\
\hline
\end{tabular}

SP, sex proportion; MP, modal pattern; Distr, distribution; AS, average size; Mat, maturity; Uni, unimodal. 
exposed site. However, the wave action may generate either positive or negative effects on the reproduction of marine invertebrates exposed to it, according to a model proposed by Denny et al. (1985).

\section{Sex-ratio}

The skewed sex-ratio toward females in DD may be a result of early maturity of males rather than an investment for somatic growth. However, many populations of marine crustaceans exhibit deviations from this ratio of unity, which may be responses to several different factors such as mortality rates, longevity, growth, behaviour and differential migration between the sexes (Wenner, 1972; Gable \& Crooker, 1977; Botelho et al., 2001). However, other species of Majoidea exhibit great plasticity in the sex-ratio (see Cobo, 2006; Teixeira et al., 2009). These patterns could be adaptive, wherein populations show different sex-ratios due to limitations imposed by the environment. However, this hypothesis needs further confirmation.

\section{Conclusion}

The populations differed in the mean size and size-range of individuals, the size of the modal class, and at morphological maturity $\left(\mathrm{CW}_{50}\right)$, in both sexes. These differences probably are determined by different hydrodynamic conditions. Therefore, it was apparent that the wave and tide action could dislodge crabs and more frequently move organisms away from the intertidal zone, as reported by many authors (see Gaylord et al., 1994; Gaylord, 2000; Denny \& Gaylord, 2002), besides causing physical injury (Denny et al., 1985).

Nevertheless, additional studies, mainly experimental ones, should be accomplished in order to clarify the influence of the strong wave action over the spider crabs population associated with algae banks, also considering the potential influence of some other features such as food availability and space competition in algae, that could contribute to the development of these population differences.

\section{ACKNOWLEDGEMENTS}

The authors are indebted to Janet $\mathrm{W}$. Reid, $\mathrm{PhD}$ for her constructive comments on early drafts of the manuscript and great help with the English language. We appreciate the helpful comments by Maria Lucia Negreiros-Fransozo, PhD. All sampling in this study has been conducted in accordance with applicable state and federal laws. This study was supported by the Universidade de Taubaté (Process \# 251/2001-PRPPG) and the Conselho Nacional de Desenvolvimento Científico e Tecnológico-CNPq (Process \# 134950/2007-0).

\section{REFERENCES}

Abrams P.A. (1988) Sexual difference in resource use in hermit crabs: consequences and causes. In Chelazzi G. and Vannini M. (eds) Behavioral adaptations to intertidal life. New York: Plenum, pp. 283-296.

Amarasekare P. (2003) Diversity-stability relationships in multitrophic systems: an empirical exploration. Journal of Animal Ecology 72, 713-724.
Baeza J.A. and Stotz W.B. (2001) Host-use pattern and host-selection during ontogeny of the commensal crab Allopetrolisthes spinifrons (H. Milne Edwards, 1837) (Decapoda: Anomura: Porcellanidae). Journal of Natural History 35, 341-355.

Baeza J.A., Schubart C.D., Zillner P., Fuentes S. and Bauer R.T. (2009) Molecular phylogeny of shrimps from the genus Lysmata (Caridea: Hippolytidae): the evolutionary origins of protandric simultaneous hermaphroditism and social monogamy. Biological Journal of the Linnean Society 96, 415-424.

Baeza J.A., Bolaños J.A., Fuentes S., Hernandez J.E., Lira C. and López R. (2010) Molecular phylogeny of enigmatic Caribbean spider crabs from the Mithrax-Mithraculus species complex (Brachyura: Majidae: Mithracinae): ecological diversity and a formal test of genera monophyly. Journal of the Marine Biological Association of the United Kingdom 90, 851-858.

Batista J.B., Leonel R.M.V. and Costa M.A.J. (2009) Características populacionais de Microphrys bicornutus (Brachyura, Mithracidae) no fital Halimeda opuntia (Chlorophyta, Halimedaceae), em área recifal submetida à visitação humana, em João Pessoa, Paraíba. Iheringia, Série Zoologia 99, 44-52.

Bertini G., Teixeira G.M., Fransozo V. and Fransozo A. (2010) Reproductive period and size at the onset of sexual maturity of mottled purse crab, Persephona mediterranea (Herbst, 1794) (Brachyura, Leucosioidea) on the southeastern Brazilian coast. Invertebrate Reproduction and Development 54, 7-17.

Botelho E.R.O., Santos M.C.F. and Souza J.R.B. (2001) Aspectos populacionais do Guaiamum, Cardisoma guanhumi Latreille, 1825, do estuário do Rio Una (Pernambuco-Brasil). Boletim Técnico Científico do CEPENE 9, 123-146.

Castaño N.C. and Campos N.H. (2003) Los cangrejos araña (Decapoda: Brachyura: Majoidea) del Caribe colombiano. Biota Colombiana 4, 261-269.

Christy J.H. and Salmon M. (1984) Ecology and evolution of mating systems of fiddler crabs (genus Uca). Biological Reviews 59, 483-509.

Cobo V.J. (2006) Population biology of spider crab, Mithraculus forceps (A. Milne-Edwards, 1875) (Majidae, Mithracinae). Crustaceana 78, $1079-1087$.

Cobo V.J. and Barros S.P. (2009) Reproductive output of the spider crab Epialtus bituberculatus (H. Milne Edwards, 1834) (Crustacea, Decapoda, Brachyura) associated with beds of the algae Sargassum cymosum (C. Agardh, 1820) on the southeastern Brazilian coast. Invertebrate Reproduction and Development 53, 53-58.

Coelho-Santos M.A. and Coelho P.A. (1995) Sazonalidade da ocorrência de crustáceos decápodos no litoral de Jaboatão dos Guararapes, Pernambuco-Brasil. Boletim Técnico Científico do CEPENE 3, $81-110$.

Conde J.E. and Díaz H. (1989) The mangrove tree crab Aratus pisonii in a tropical estuarine coastal lagoon. Estuarine, Coastal and Shelf Science $28,639-650$.

Creasey S., Rogers A.D., Tyler P., Young C. and Gage J. (1997) The population biology and genetics of the deep-sea spider crab, Encephaloides armstrongi Wood-Mason 1891 (Decapoda: Majidae). Philosophical Transactions of the Royal Society, B 352, 365-379.

Denny M.V., Daniel T.L. and Koehl M.A.R. (1985) Mechanical limits to size in wave swept organisms. Ecological Monographs 55, 69-102.

Denny M. and Wethey D. (2001) Physical processes that generate patterns in marine communities. In Bertness M.D., Gainess S.D. and Hay M.E. (eds) Marine community ecology. Sunderland, MA: Sinauer Associates, pp. 3-37.

Denny M. and Gaylord B. (2002) The mechanics of wave-swept algae. Journal of Experimental Biology 205, 1355-1362. 
DeVries M.C., Epifanio C.E. and Dittel A.I. (1983) Reproductive periodicity of the tropical crab Callinectes arcuatus Ordway in Central America. Estuarine, Coastal and Shelf Science 17, 709-716.

Díaz H. and Conde J.E. (1989) Population dynamics and life of mangrove crab Aratus pisonii (Brachyura, Grapsidae) in a marine environment. Bulletin of Marine Science 45, 148-163.

Gable M.F. and Crooker R.A. (1977) The salt marsh amphipod Gammarus palustris Bousfield, 1969 at the northern limit of its distribution. I. Ecology and life cycle. Estuarine, Coastal and Shelf Science 5, $123-134$.

Gaylord B. (2000) Biological implications of surf-zone flow complexity Limnology and Oceanography 45, 174-188.

Gaylord B., Blanchette C.A. and Denny M.W. (1994) Mechanical consequences of size in wave-swept algae. Ecological Monographs 64, 287-313.

Gherardi F. and Micheli F. (1989) Relative growth and population structure of the freshwater crab, Potamon potamios palestinensis, in the Dead Sea area (Israel). Israel Journal of Zoology 36, 133145.

Guarnieri G., Terlizzi A., Bevilacqua S. and Fraschetti S. (2009) Local vs regional effects of substratum on early colonization stages of sessile assemblages. Biofouling 25, 593-604.

Haefner P.A. Jr (1990) Morphometry and size at maturity of Callinectes ornatus (Brachyura, Portunidae) in Bermuda. Bulletin of Marine Science 46, 274-286.

Hartnoll R.G. (1982) Growth. In Abele L.G. (ed.) The biology of Crustacea. Volume 2. Embryology morphology and genetics. New York: Academic Press, pp. 111-195.

Hartnoll R.G. and Bryant A.D. (1990) Size-frequency distributions in decapod Crustacea-the quick, the dead, and the castoffs. Journal of Crustacean Biology 10, 14-19.

Jackson A.C. (2010) Effects of topography on the environment. Journal of the Marine Biological Association of the United Kingdom 90, 169-192.

Jones M.B. and Simons M.J. (1983) Latitudinal variation in reproductive characteristics of a mud crab, Helice crassa (Grapsidae). Bulletin of Marine Science 33, 656-669.

Keunecke K.A., D'Incao F. and Fonseca D.B. (2007) Growth and mortality of Hepatus pudibundus (Crustacea: Calappidae) in southwestern Brazil. Journal of the Marine Biological Association of the United Kingdom 87, 885-891.

Litulo C. (2004) Reproductive aspects of a tropical population of the fiddler crab Uca annulipes (H. Milne Edwards, 1837) (Brachyura: Ocypodidae) at Costa do Sol Mangrove, Maputo Bay, southern Mozambique. Hydrobiologia 525, 167-173.

López-Greco L.S., Hernández J.E., Bolaños J., Rodríguez E.M. and Hernández G. (2000) Population features of Microphrys bicornutus Latreille, 1825 (Brachyura, Majidae) from Isla Margarita, Venezuela. Hydrobiologia 439, 151-159.

Mantelatto F.L.M., Faria F.C.R. and Garcia R.B. (2003) Biological aspects of Mithraculus forceps (Brachyura: Mithracidae) from Anchieta Island, Ubatuba, Brazil. Journal of the Marine Biological Association of the United Kingdom 83, 789-791.

Melo G.A.S. (1996) Manual de identificação dos Brachyura (caranguejose siris) do litoral brasileiro. São Paulo: Plêiade/FAPESP.

Melo G.A.S. (1998) Malacostraca-Eucarida. Brachyura. Oxyrhyncha and Brachyrhyncha. In Young P.S. (ed.) Catalogue of Crustacea of Brazil. Rio de Janeiro: Museu Nacional (Série Livros No. 6), pp. 455-515.

Mura M., Orru F. and Cau A. (2005) Size at sexual maturity of the spider crab Anamathia rissoana (Decapoda: Majoidea) from the Sardinian Sea. Journal of Crustacean Biology 25, 110-115.
Negreiros-Fransozo M.L., Fransozo A. and Reigada A.L.D. (1994) Biologia populacional de Epialtus brasiliensis Dana, 1852 (Crustacea, Majidae). Revista Brasileira de Biologia 54, 173-180.

Negreiros-Fransozo M.L. and Fransozo A. (2001) Larval development of Epialtus bituberculatus H. Milne Edwards, 1834 (Crustacea: Decapoda: Brachyura: Majidae) with comments on majid larvae from the southwestern Atlantic. Proceedings of the Biological Society of Washington $114,120-138$.

Ng P.K.L., Guinot D. and Davie P.J.F. (2008) Systema brachyurorum: Part I. An annotated checklist of extant brachyuran crabs of the world. Raffles Bulletin of Zoology 17, 1-208.

Pimenta A.M., Barutot R.A., D'Incao F. and Fonseca D.B. (2005) Growth of Armases rubripes (Rathbun, 1897) in the estuary of the Lagoa dos Patos, Southern Brazil. Nauplius 13, 183-189.

Pinheiro M.A.A. and Fransozo A. (2002) Reproduction of the speckled swimming crab Arenaeus cribrarius (Brachyura: Portunidae) on the Brazilian coast near $23^{\circ} 30^{\prime}$ S. Journal of Crustacean Biology 22, $416-$ 428.

Sampedro M.P., Gonzalez-Gurriaran E., Freire J. and Muino R. (1999) Morphometry and sexual maturity in the spider crab Maja squinado (Decapoda; Majidae) in Galicia, Spain. Journal of Crustacean Biology 19, $578-593$.

Sanz-Brau A. (1989) Ciclo biológico de Acanthonyx lunulatus (Risso, 1816) (Crustacea: Decapoda: Majidae) en las costas del levante ibérico (Mediterráneo occidental). Scientia Marina 53, 857-861.

Sokal R.R and Rohlf F.J. (1995) Biometry. 3rd edition. New York: W.H. Freeman \& Co.

Széchy M.T.M., Veloso V.G. and Paula E.J. (2001) Brachyura (Decapoda, Crustacea) of phytobenthic communities of the sublittoral region of rocky shores of Rio de Janeiro and São Paulo, Brazil. Tropical Ecology 42, 231-242.

Stearns S.C. (1992) The evolution of life history. New York: Oxford University Press.

Teixeira G.M., Fransozo V., Castilho A.L., Costa R.C. and Freire F.A.M. (2008) Size distribution end sex ratio in the spider crab Epialtus brasiliensis (Dana 1852) associated with seaweed on a rocky shore in southeastern Brazil (Crustacea, Decapoda, Brachyura, Majoidea, Epialtidae). Senckenbergiana Biologica 88, 169-176.

Teixeira G.M., Fransozo V., Cobo V.J. and Hiyodo C.M. (2009) Population features of the spider crab Acanthonyx scutiformis (Dana 1851) (Crustacea, Majoidea, Epialtidae) associated with rocky-shore algae from southeastern Brazil. Pan-American Journal of Aquatic Sciences 4, 87-95.

Villalejo-Fuerte M., Ceballos-Vázquez B.P., Arellano-Martínez M. and García-Domínguez F. (2001) Contribution to the biology of the spider crabs Maiopsis panamensis Faxon, 1893 and Stenocionops ovata (Bell, 1835) (Decapoda: Majoidea) from the Gulf of California, Mexico. Revista de Biología Marina y Oceanografía 36, 199-203.

Warner G.F. (1967) The life history of the mangrove tree crab Aratus pisonii. Journal of Zoology 153, 321-335.

Wenner AM. (1972) Sex ratio as a function of size in marine Crustacea. American Naturalist 106, 321-350.

Wieters E.A., Salles E., Januario S.M. and Navarrete S.A. (2009) Refuge utilization and preferences between competing intertidal crab species. Journal of Experimental Marine Biology and Ecology 374, 37-44.

and

Zar J.H. (2010) Biostatistical analysis. 5th edition. Upper Saddle River, NJ: Prentice-Hall. 
Correspondence should be addressed to:

S.P. Barros-Alves

Departamento de Zoologia

Instituto de Biociências
Universidade Estadual Paulista-UNESP

Distrito de Rubião Junior, s/n, CEP: 18618-970, Botucatu, São Paulo, Brasil

email: barros_samara@hotmail.com 